Social Work \& Education

๑) SW\&E, 2019

УДК 364.075.2

DOI: $10.25128 / 2520-6230.19 .3 .2$
Кононович, Д. (2019). Проблеми соціального захисту сімей, що опинились в складних життєвих обставинах та шляхи їх вирішення. Social Work and Education. Vol. 6, No. 3. Ternopil-Aberdeen, 2019. pp. 240-248. DOI: 10.25128/2520-6230.19.3.2

\section{ПРОБЛЕМИ СОЦІАЛЬНОГО ЗАХИСТУ СІМЕЙ, ЩО ОПИНИЛИСЬ В СКЛАДНИХ ЖИТТЕВИХ ОБСТАВИНАХ ТА ШЛЯХИ ЇХ ВИРІШЕННЯ}

\author{
Дар'я Кононович, \\ аспірантка Луганського \\ національного університету \\ імені Тараса Шевченка \\ спеціальності "Соціальна \\ робота", \\ м. Старобільськ, Україна \\ 27dr.kononovich@gmail.com
}

Article history:

Received: May 28, 2019

1st Revision: July 02, 2019

Accepted: September 30, 2019
АНОТАЦІЯ. В основу роботи покладена ідея визначення особливостей та напрямків вдосконалення соціального захисту сімей, що опинились в складних життєвих обставинах.

Автор розкриває сутність і зміст визначення поняття „соціальний захист сімей”, характеризує особливості діяльності центрів соціальних служб для сім'ї, дітей та молоді у сфері соціального захисту сімей, що опинились в складних життєвих обставинах, визначає організаційно-правові засади соціального захисту сімей, що опинились в складних життєвих обставинах.

Здійснено аналіз соціального захисту сімей, що знаходяться в складних життєвих обставинах в Україні в сучасних умовах та наведено шляхи його удосконалення.

Ключові слова: сім'я; соціальний захист; складні життєві обставини; соціальна служба; соціальні послуги. 


\section{Вступ}

У сучасних умовах в Україні існує державна модель соціальної підтримки сім’ї 3 дітьми, що має вже певні позитивні здобутки, серед яких: активізація роботи 3 сім'єю, посилення соціального захисту окремих категорій сімей, розширення форм та засобів впливу на процеси розвитку та функціонування сім’і тощо.

Але, поряд із цим, необхідно відмітити відсутність системності та послідовності дій органів влади усіх рівнів щодо вирішення проблеми сімейного неблагополуччя. Також нерегулярним $є$ здійснення переважної більшості соціально захисних заходів, зокрема через недостатній рівень фінансування, нерозвиненість та нерівномірність розвитку мережі відповідних соціальних служб залежно від регіону та типу населеного пункту існує нерівність доступу різних категорій сімей до соціальних послуг. Отже, все ще $є$ підстави говорити про необхідність формування цілісної системи заходів державної сімейної політики, вироблення адекватних механізмів, які б протидіяли тій сукупності взаємопов'язаних та взаємозумовлених чинників, що спричиняють проблеми розвитку і функціонування сім’і, їі неблагополуччя.

\section{Аналіз останніх досліджень і публікацій}

Проблеми соціального захисту населення та його регулювання залишаються в центрі постійного наукового інтересу вітчизняних та зарубіжних вчених (С.І. Бичков, Н.Б. Болотіна, К.В Бориченко, М.М. Денисюк, Н.І. Кривоконь, Л.В. Кулачок, Г.М. Кучер, І.Л. Лемещук, Т. А. Міщенко).

Вивченню теоретико-методичних питань соціально-педагогічної та соціальної роботи із сім'ями різних типів присвячено роботи таких науковців, як О.В. Безпалько, 3. Г. Зайцева, І.Д. Звєрєва, Т.С. Зубкова, А.Й. Капська, Н.П. Краснова, В.В. Ремезова, Т.В. Семигіна, І. С. Сьомкіна, І. М. Трубавіна, С.В. Толстоухова та ін.

Серед наукових робіт, які вивчають різні аспекти роботи з дітьми і сім'ями групи ризику, особливий інтерес для нас мають наукові розробки С. М. Вакуленко, О.М. Мороз, В.В. Ремезової, І. С. Сьомкіної, С.В.Толстоухової, К.С. Шендеровського.

Аналіз сучасних соціально-педагогічних досліджень засвідчив, що за останнє десятиріччя 3'явилось значна кількість науково-методичної та педагогічної літератури, яка відповідає сучасним запитам і потребам соціальної роботи 3 сім'єю як у теоретичному, так і у практичному плані. В той же час, діяльність центрів соціальних служб для сім'ї, дітей та молоді у сфері вирішення проблем сім'ї, що опинились в складних життєвих обставинах не стала об'єктом системних науково-педагогічних пошуків, що обумовлює актуальність досліджень в цій сфері. 
Мета статті - визначити особливості та напрямки вдосконалення діяльності центрів соціальних служб для сім'ї, дітей та молоді (далі - ЦСССДМ) у сфері соціального захисту сімей, що опинились в складних життєвих обставинах.

\section{Основна частина}

Актуальність і соціальна значущість проблеми сімейного неблагополуччя зумовлена необхідністю розв'язання низки протиріч, які склались між: потребою держави в ефективно функціонуючій системі соціальних служб щодо соціальної підтримки та допомоги сім'ям, які опинилися у складних життєвих обставинах та відсутністю належних організаційно-педагогічних умов i ресурсів побудови ефективної роботи ЦСССДМ; державною та суспільною потребою активізації ресурсів сім'ї на вирішення життєвих проблем і не готовністю членів кризових сімей до цієї діяльності у зв'язку зі відсутністю необхідного соціально-психологопедагогічного ресурсу; усвідомленням власних проблем, мотивації на взаємодію щодо виходу з кризи спільно зі державними соціальними інституціями та недостатньою теоретико-методичною підготовленістю самих фахівців ЦСССДМ до роботи з сім'ями в складних життевих обставинах.

Зазначимо, що соціальний захист сімей $з$ дітьми - це комплекс юридичних, організаційних, економічних та фінансових заходів, спрямованих на забезпечення реалізації сім'ями 3 дітьми права на захист від несприятливих наслідків соціальних ризиків, їх подолання або пом'якшення (Шевчук, 2003, с. 86).

Сім'єю, що опиниласяв складних життєвих обставинах, проведене дослідження дозволяє вважати малу соціальну групу, члени якої об'єднані виконанням сімейних функцій, емоційнимизв'язками, взаємними юридичними та моральними зобов'язаннями таперебувають у таких життєвих обставинах, що не сприяють повноцінному розвитку та задоволенню потребкожного члена сім'ї, порушують їх функціонування, права та перешкоджають самостійному виконанню своїх обов'язків (Капська, 2012).

В Україні діє широкий спектр законів та нормативно-правових актів 3 питань соціальної підтримки сім'ї у складних життєвих обставинах, охорони та соціального захисту дитинства, які грунтуються на міжнародних стандартах права та регламентують діяльність центрів соціальних служб для сім'ї, дітей та молоді щодо подолання сімейного неблагополуччя.

Незважаючи на існування доволі широкого правового поля, $\epsilon$ потреба удосконалення чинного законодавства України щодо вирішення проблем захисту сім'ї та дитинства, створення системи дієвих механізмів впровадження i контролю за виконанням законів України щодо вирішення означених проблем, а також координації та врегулювання відносин сім'ї, держави, суспільства, батьків 
та дітей щодо забезпечення ефективної державної соціальної сімейної політики та попередження явища сімейного неблагополуччя.

Спеціальними закладами, що займаються вирішенням проблем сімейного неблагополуччя i надають соціальні послуги сім'ям, дітям та молоді, які перебувають у складних життєвих обставинах є центри соціальних служб для сім'ї, дітей та молоді, та утворюють державну ланку, що здійснює соціальну роботу з сім'єю, дітьми та молоддю (Slozanska, 2018). Усі центри об'єднані в єдиний державний механізм з реалізації соціальної політики щодо сім’ї дітей та молоді.

У результаті аналізу сутнісних характеристик існуючої практики роботи центрів соціальних служб для сім’і, дітей та молоді з неблагополучною сім’єю 3'ясовано, що основний зміст даної роботи полягає у забезпеченні сім'ї, яка потрапила у сімейну кризу комплексом соціальних послуг (соціальне обслуговування, матеріально-фінансова та соціальна допомога), проведенні соціального інспектування, організації соціального супроводу та соціальної (соціально-педагогічної) профілактичної та реабілітаційної роботи.

Аналіз нормативно-правового та організаційного аспектів функціонування системи соціального захисту сімей в Україні свідчить про існування певних проблем у сфері соціальної роботи та надання соціальних послуг сім'ям: недосконалість нормативно-правової бази; нерозробленість механізму ліцензування професійної діяльності у сфері надання соціальних послуг; відсутність повноцінного ринку соціальних послуг; недостатня представленість на ринку соціальних послуг недержавних суб'єктів; відсутність єдиних критеріїв оцінки якості та ефективності діяльності соціальних служб; низький престиж соціальної роботи у суспільстві; недостатнє загальне фінансування системи соціального захисту в цілому, обмеженість матеріальних ресурсів центрів соціальних служб для сім’ї, дітей та молоді у процесі соціального супроводу; неукомплектованість штату фахівців центрів соціальних служб для сім’ї, дітей та молоді, недостатня кількість висококваліфікованих кадрів для роботи 3 неблагополучними сім'ями.

Вітчизняна система соціального обслуговування осіб, які перебувають у складних життєвих обставинах характеризується надмірною централізацією i державною монополізацією надання соціальних послуг, базується на непрозорих пільгах i неефективних соціальних грошових виплатах, які надаються забюрократизованою широкою мережею державних i комунальних закладів соціального захисту та соціальних служб.

Таким чином, наведені дані, підтверджують нашу думку про необхідність розроблення ефективних організаційно-педагогічних умов діяльності центрів соціальних служб сім'ї, дітей та молоді щодо подолання сімейного 
неблагополуччя відповідно до типу сім'ї, що враховували б, по-перше, інформаційно-аналітичну складову забезпечення системи попередження сімейного неблагополуччя, обліку та супроводу неблагополучних сімей; по-друге, комплексний підхід до роботи 3 неблагополучною сім'єю, який забезпечить: діагностику соціального середовища сім'ї та причин, які продукують сімейні кризи і неблагополуччя, організацію профілактичної роботи та соціальнопедагогічної допомоги сім'ї, що опинилася у кризі, для іiї успішної реадаптації у суспільстві; по-третє, індивідуалізацію роботи з кожною конкретною сім'єю, яка опинилася у кризі, на принципах варіативного та програмно-цільового підходів.

Резюмуючи все зазначене, можна зробити висновок, що діагностика ефективності роботи ЦСССДМ з неблагополучними сім'ями засвідчила, що системно-комплексною діяльністю центру щодо подолання сімейного неблагополуччя охоплено лише четверту частину сімей досліджуваної категорії від загальної кількості тих, які перебувають на обліку.

Причинами недостатньої ефективності роботи ЦСССДМ 3 сім'ями, які опинилися у складних життєвих обставинах, є певні об'єктивні та суб'єктивні чинники, які мають як організаційно-педагогічний, змістово-процесуальний (щодо діяльності ЦСССДМ), так і приватно-особистісний (щодо ролі та участі сімей) характер.

3 метою визначення сутнісних орієнтирів покращення ефективності соціальнопедагогічної роботи ЦСССДМ визначені напрями удосконалення даної роботи за об'єктивними та суб'єктивними чинниками, а саме:

1. За суб'єктивними чинниками:

- розробка чіткого алгоритму системно-комплексної організації роботи 3 сім'єю, категорії СЖО відповідно до типів сімейного неблагополуччя, а не „взагалі сім'ї СЖО” як це є сьогодні. Мова йде про конкретну послідовність дій та заходів фахівців центру соціальних служб щодо надання сім'ї необхідної соціально-педагогічної допомоги та підтримки відповідно до іiі потреб, дій спрямованих на виведення сім'ї зі стану сімейного неблагополуччя;

- відмова від патерналістських взаємин з клієнтами і організація взаємодії на партнерських умовах;

- створення умов для підвищення професіоналізму і кваліфікації фахівців шляхом мінімізації плинності кадрів, залучення волонтерів, відкритості інтелектуальних дискусій i стимулювання зацікавленості в підвищенні кваліфікації, збільшення кількості професійно-розвиваючих заходів;

- впровадження супервізії як ефективної технології розвитку професійної компетентності персоналу; 
- удосконалення інституту державних соціальних інспекторів 3 метою можливості організації контролю над цільовим використанням допомоги одержувачем;

- автоматизація системи надання „шаблонних” видів допомоги шляхом застосування автоматизованих систем і розробки відповідного програмного забезпечення з надання соціальних послуг. За допомогою таких терміналів будьяка людина отримає можливість оперативної i достовірної консультації (інформативного або юридичного характеру);

- створення власного позитивного іміджу серед населення, підвищення інформованості різних типів сімей про можливості та механізми отримання соціальних послуг;

- створення особистого „інтерактивного кабінету” одержувачів соціальних послуг, в якому містилася б інформація про послуги, які в минулому отримував індивід.

2. За об' єктивними чинниками:

- покращення інфраструктурного забезпечення надання соціальних послуг шляхом відкриття кризових центрів зі стаціонаром, кабінеті психологічної та юридичної допомоги, громадських центрів дозвілля;

- оптімізація системи професійної підготовки i перепідготовки фахівців завдяки проведення всеукраїнськіх навчальних форумів соціальних працівників, створення інформаційно-навчальних ресурсів, організації закордонного стажування та програм обміну досвідом;

- спрощення процедури отримання соціальних послуг 3 орієнтацією насамперед на потреби сім'ї i на ¥ii право у виборі форм соціального обслуговування;

- надання послуг зі сприяння в формуванні груп самодопомоги;

- впровадження інноваційних форм надання соціальних послуг, шляхом покращення методичного забезпечення фахівців, ознайомлення 3 новітніми тенденціями;

- переорієнтація діяльності ЦСССДМ та ресурсів 3 подолання наслідків сімейного неблагополуччя на його профілактику, тобто на зосередження уваги державних соціальних установ та громадських інституцій на всіх без винятку сім'ях відповідно до їх потреб, тобто превентивний напрям соціальнопедагогічної роботи у громаді, спрямований на те, щоб не допустити потрапляння сім’ї в категорію „кризовоі”, „зі складними життєвими обставинами”. Мета даного напряму діяльності - формування власних соціально-психологопедагогічних ресурсів сім’ї щодо подолання і виходу з сімейної кризи (тобто озброєння членів сімей необхідними знаннями, практичними уміннями i навичками щодо попередження і подолання сімейного неблагополуччя); 
- розширення співпраці з навчальними закладами, які здійснюють підготовку професійних соціальних працівників щодо можливості проходження навчальної практики та подальшого працевлаштування кваліфікованих спеціалістів.

\section{Висновки}

Дослідження не вичерпує всіх аспектів проблеми. Перспективу подальшого наукового пошуку вбачаємо в дослідженні комплексу проблем, пов'язаних 3 критеріями оцінки життєдіяльності сім'ї як соціального інституту; визначенні умов і показників ефективності соціального захисту; впровадженні зарубіжного досвіду соціальної роботи з кризовими категоріями сімей.

\section{Література}

Шевчук, П. І. (2003). Соціальна політика. Львів: Світ, 400 с.

Капська, А. Й. (2012).Соціальний супровід різних категорій сімей та дітей : навч. Посібник. К.: Центр учбової літератури, 232 с.

Slozanska, H. (2018). Are future social workers of bachelor degree ready to provide integrated social services in the territorial community in Ukraine. Social work and education, 5(4), P. 84-103. 


\title{
PROBLEMS OF SOCIAL PROTECTION OF FAMILIES INTENDED IN COMPLEXIVE LIVING CIRCUMSTANCES AND WAYS OF THEIR SOLUTION
}

\author{
Daria Kononovych, Graduate student (Ph.D. in Social Work), Luhansk Taras \\ Shevchenko National University, Starobilsk, Ukraine
}

\begin{abstract}
Resolving the problem of spreading family disadvantages in Ukraine needs to update the legal and regulatory framework for legislation on the activities of social service centers for families, children and youth with crisis families, developing and implementing a clear, integrated system of social and pedagogical work of the Centers, taking into account the diversity of causes and needs of the family according to the type of family disadvantage.

The work is based on the idea of identifying features and directions for improving the activities of social service centers for families, children and youth in the field of social protection of families in difficult living conditions.

The author reveals the essence and content of the definition of the concept of "social protection of families", describes the peculiarities of the activities of social service centers for families, children and young people in the field of social protection of families in difficult living conditions, defines the organizational and legal principles of social protection of families, which were in difficult life circumstances.

The analysis of social protection of families in difficult living conditions in Ukraine under current conditions is carried out and ways of its improvement are presented.

The level and dynamics of social and economic indicators is analyzed which display a standard of living and social security of the population in a nation-wide and regional section. The organization-economic model of the functional coordination and system interaction of social development and social protection is developed.

Specific suggestions and recommendations for the improvement of the national legislation on social protection and the practice of its application are made.

Practical work is that the proposed theoretical positions and methodological approaches can be used to improve the organizational and legal principles of social service development in Ukraine; increasing the effectiveness of the social management bodies and social services that provide social services to families; professional training of social pedagogues and specialists in social work in higher educational institutions of Ukraine.
\end{abstract}

Key words: family; social protection; difficult life circumstances; social service; social services. 


\section{References}

Shevchuk, P. I. (2003). Sotsialna polityka [Social policy]. Lviv: Svit. [in Ukrainian].

Kapska, A. Y. \& Piesha, I. V. (2012). Sotsialnyi suprovid riznykh katehorii simei ta ditei [Social support for different categories of families and children]. Kyiv: Tsentr uchbovoi literatury. [in Ukrainian].

Slozanska, H. (2018). Are future social workers of bachelor degree ready to provide integrated social services in the territorial community in Ukraine. Social work and education, 5(4), P. 84-103. 